\title{
NeW APPROACH OF DETERMINING CUTTING FORCES
}

\author{
Geiger, G.; Puschitz, F. \& Bleicher, F.
}

Abstract: The $k c_{1.1}$ values found in the common publications or provided by steel suppliers are often limited to standard materials like C45. Information on testing conditions are usually not available. Additional to this a lot of tests for standard materials were done in the early days of production engineering with pure mechanical force measurement systems and cutting machines which are inadequate to modern measurement and production standards.

To shift determining of $k_{1.1}$ values to state of the art control and measurement technology and make them reproducible, a procedure for turning was created, which fits all types of materials. In the next step the correction factors used for calculating the cutting forces and power should be integrated into new types of equation.

Key words: basic cutting, $k c_{1.1}$, specific cutting force
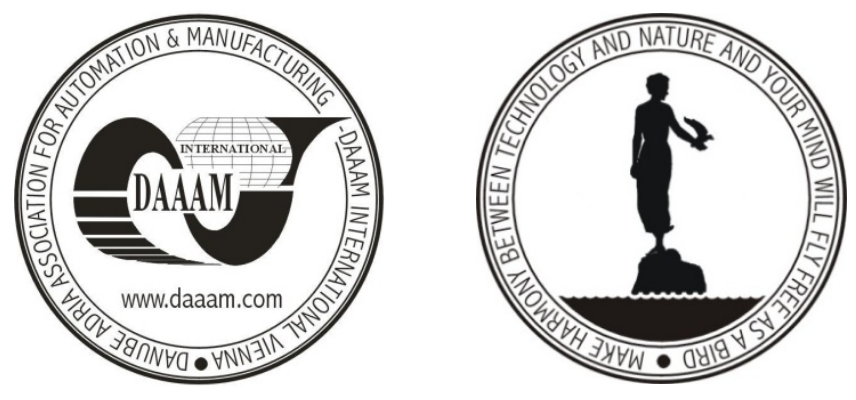

Authors' data: Dipl.- Ing. Geiger, G[eorg]; Dipl.- Ing. Puschitz, F[alko]; Prof. Dr. Bleicher, F[riedrich], Vienna University of Technology - Institute of Production Engineering, Landstraßer Hauptstraße 152, 1030, Vienna, AT, geiger@ift.at, puschitz@ift.at, bleicher@ift.at

This Publication has to be referred as: Geiger, G[eorg]; Puschitz, F[alko] \& Bleicher, F[riedrich] (2008). New Approach of Determining Cutting Forces, Chapter 25 in DAAAM International Scientific Book 2008, pp. 287-300, B. Katalinic (Ed.), Published by DAAAM International, ISBN 978-3-901509-66-7, ISSN 1726-9687, Vienna, Austria

DOI: $10.2507 /$ daaam.scibook.2008.25 